\title{
DÜBLIN
}

Technological University Dublin

ARROW@TU Dublin

2012-11-12

\section{Integration of Inverted-F Antenna with Solar Cell Substitute}

Oisin O'Conchubhair

Technological University Dublin, oisin.oconchubhair@mydit.ie

Patrick McEvoy

Technological University Dublin, patrick.mcevoy@tudublin.ie

Max Ammann

Technological University Dublin, max.ammann@tudublin.ie

See next page for additional authors

Follow this and additional works at: https://arrow.tudublin.ie/ahfrccon

Part of the Systems and Communications Commons

\section{Recommended Citation}

O'Conchubhair, O. (2012) Integration of Inverted-F Antenna with Solar Cell Substitute, LAPC Loughborough Antennas \& Propagation Conference, Loughborough, UK, pp. 1-4, 12/11/2012, doi:10.1109/LAPC.2012.6403047

This Conference Paper is brought to you for free and open access by the Antenna \& High Frequency Research Centre at ARROW@TU Dublin. It has been accepted for inclusion in Conference Papers by an authorized administrator of ARROW@TU Dublin. For more information, please contact arrow.admin@tudublin.ie, aisling.coyne@tudublin.ie,gerard.connolly@tudublin.ie.

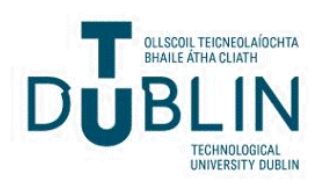




\section{Authors}

Oisin O'Conchubhair, Patrick McEvoy, Max Ammann, and Giuseppe Ruvio

This conference paper is available at ARROW@TU Dublin: https://arrow.tudublin.ie/ahfrccon/36 


\title{
Integration of Inverted-F Antenna with Solar Cell Substitute
}

\author{
Oisin O’Conchubhair, Patrick McEvoy, Max J. Ammann, Giuseppe Ruvio \\ Antenna \& High Frequency Research Centre \\ School of Electronic and Communications Engineering \\ Dublin Institute of Technology \\ Kevin St., Dublin8, Ireland \\ oisin.oconchubhair@mydit.ie,max.ammann@dit.ie,patrick.mcevoy@dit.ie
}

\begin{abstract}
A study into the effect of a solar cell lattice on the performance of an Inverted-F antenna is presented. An FR-4 substrate with a lattice of copper electrodes printed on one side and a solid copper ground plane on the other is used to represent a polycrystalline solar cell. The effect of the lattice orientation on the performance of the Inverted-F antenna is discussed.
\end{abstract}

\section{Keywords-Printed Inverted-F Antenna, Integration, Solar Cell.}

\section{INTRODUCTION}

In many wireless communication applications access to a power grid may not be feasible due to remote location. Hence the use of wireless communications powered from photovoltaic sources is attractive. The disadvantage of this concept is the greater demand for the surface area required to mount both conventional photovoltaic systems and antenna systems separately. It is therefore necessary to integrate these systems with minimal impact on performance. Many attempts have been made to couple antennas and solar cells, in some cases a solar cell is simply positioned above a radiating element [1][3]. Here, the solar cells were positioned to allow the antenna to radiate leaving unutilised surface space. Another attempt used the solar cell as the radiating element of an antenna [4]. This method uses an aperture coupled feed to excite the solar cell without interfering with its DC operation. Use of the solar cell as an RF ground for printed antennas is another common method of integration [5]-[6]. The drawback in most of these cases is the reduction in incident light reaching the solar cell as a result of the antennas position in front of the solar cell.
This paper proposes the integration of a printed Inverted-F Antenna (IFA) with a polycrystalline photovoltaic solar cell using the photovoltaic cell as the antenna ground plane. The IFA protrudes from the ground plane which means the surface area required to mount this antenna is greatly reduced. The antenna can then be optimised to reduce its height which reduces shadowing and in turn reduces the impact on the solar cell performance. However decreasing the height of the IFA will reduce its bandwidth [7]. There are however many solutions to this problem as these antenna types are commonly used in laptop design [8]-[10]. In some cases adjustment to the size of the ground plane and grounding stub are sufficient to achieve a higher bandwidth [8]. A better method is to consider the IFA as two separate resonating structures, an inverted L monopole and a slot created between the grounding stub and the ILA [10]. This allows optimisation of both of these resonators to give a combined bandwidth much greater than that achievable from the monopole alone. It is also possible to introduce a second resonance by adding a spiral into the resonating element of the IFA [11]. This paper will focus on aspects of solar cell integration rather than IFA optimisation.

\section{IFA SOLAR ANTENNA}

A $10 \mathrm{~mm}$ high IFA was first optimised on a solid copper ground plane and then transferred to a latticed structure representing a solar cell. The antenna is a printed type IFA created on FR-4 substrate to act as a supporting structure, as shown in Fig. 1.

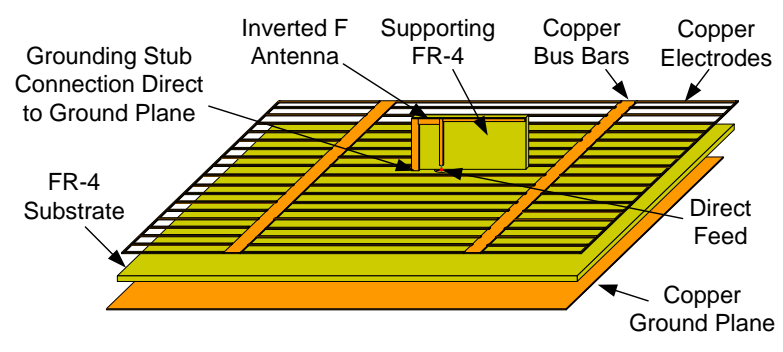

Figure 1. Antenna Configuration

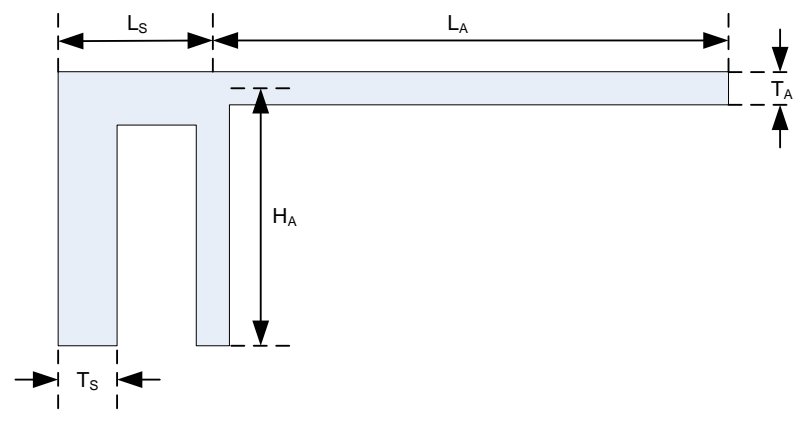

Figure 2. Antenna Dimensions 
TABLE I. SIMULATED RESUltS FOR ANTENNA ONLY TEST

\begin{tabular}{|l|c|c|c|}
\hline \multicolumn{1}{|c|}{ Antenna Orientation } & $\begin{array}{c}\text { Frequency } \\
(\mathbf{G H z})\end{array}$ & $\begin{array}{c}\mathbf{- 1 0} \text { dB Bandwidth } \\
(\boldsymbol{\%})\end{array}$ & $\begin{array}{c}\text { Gain } \\
(\mathbf{d B i})\end{array}$ \\
\hline Parallel to Lattice & 2.393 & 6.74 & 3.388 \\
\hline Perpendicular to Lattice & 2.385 & 6.23 & 3.457 \\
\hline FR-4 Covered Ground Plane & 2.416 & 5.66 & 3.873 \\
\hline
\end{tabular}

The dimensions of the IFA are $L_{A}=21 \mathrm{~mm}, H_{A}=10 \mathrm{~mm}$, $T_{A}=0.784 \mathrm{~mm}$ and the grounding stub dimensions are $L_{S}=$ $4.019 \mathrm{~mm}$ and $T_{S}=1.5 \mathrm{~mm}$. Optimisation of the design was carried out using the time domain solver of CST Microwave Studio. The IFA is fed using a $50 \mathrm{Ohm}$ coplanar waveguide (CPW) transmission line created on a $0.4 \mathrm{~mm}$ thick FR-4 substrate with $\varepsilon_{\mathrm{r}}=4.3$. The transmission line extends $5 \mathrm{~mm}$ out from the lattice to prevent shorting between the front and rear contacts of the solar cell when the SMA is connected.

Solar cells are made up of three main elements, an anode front contact, a cathode rear contact and a semiconductor material between the contacts. In most cases the cathode is a solid sheet of conductive material and the anode is made up of a number of electrodes designed to maximise the level of insolation into the semiconductor material while maximising the generated power output of the solar cell. The semiconductor material usual consists of multiple doped regions of semiconductor material which have been positively or negatively doped. When combined the electrons in these layers adjust to a state equilibrium until photons from sunlight entering the material distort the equilibrium causing the electrons to flow through the external circuit to equalise the layers once more. In this way electricity is produced by the solar cell. In the event that a photon is not absorbed by the material it will be released in the form of heat, this rise in temperature changes the properties of the semiconductor material which usually reduces the efficiency of the solar cell.

A solar cell was simulated using a $0.4 \mathrm{~mm}$ thick substrate of FR-4 with a lattice of copper electrodes printed on one side and a solid copper ground plane on the other. The lattice is made up of $57 \times 0.1 \mathrm{~mm}$ wide copper electrodes. These electrodes are separated by a gap of $2.54 \mathrm{~mm}$ and connected at both ends by another $0.1 \mathrm{~mm}$ thick electrode. The electrodes are also connected by two $2 \mathrm{~mm}$ wide bus bars spread $74.18 \mathrm{~mm}$ apart. This substitution removes the effects caused by variation in the dielectric constant of the solar cell semiconductor due to varying light intensities between measurements thus ensuring any variation between measurements is a result of lattice orientation.

To analyse the contributing factors, simulations were carried out in which the IFA grounding stub was connected directly to the ground plane through the substrate and the antenna was fed directly through the substrate as shown in Fig. 1. In each case the antenna is connected to the cathode of the solar cell leaving the anode unconnected from the antenna circuit. This configuration would not be possible in reality as it would damage the brittle solar cell. These simulations show the effect of the lattice on the antenna only i.e. removes the effect of the transmission line. For reference, these are compared to

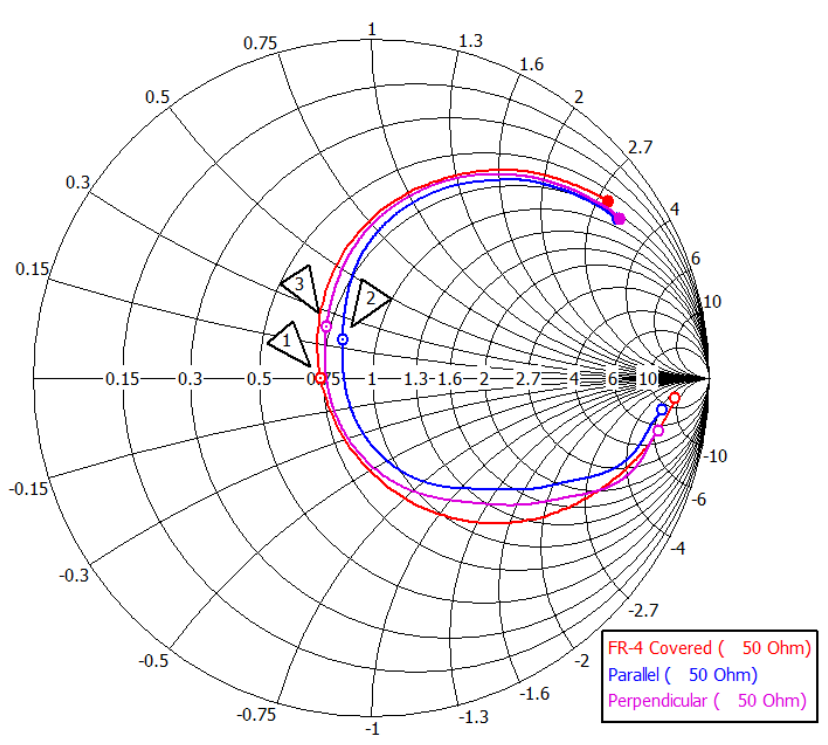

Figure 3. Impedance at $2.425 \mathrm{GHz}$

the case where the lattice is removed, leaving an FR4 covered ground plane for the IFA.

The antenna results, given in TABLE I, show increased losses with the introduction of the lattice. The FR-4 covered ground plane without lattice was resonant at $2.416 \mathrm{GHz}$, had a bandwidth of $5.66 \%$ and a gain of $3.873 \mathrm{dBi}$. The perpendicular lattice orientation (Fig 5) was resonant at $2.385 \mathrm{GHz}$, had a bandwidth of $6.23 \%$ and a gain of $3.457 \mathrm{~dB}$. The parallel orientation (Fig 4) was resonant at $2.393 \mathrm{GHz}$, had a bandwidth of $6.74 \%$ and a gain of $3.388 \mathrm{GHz}$. Fig. 3 shows the impedance of the three antenna orientations, it can be seen that the addition of the lattice inductively loads the antenna. Ground plane currents for the parallel lattice orientation, which oppose the antenna current, had the largest magnitude which accounts for its reduced performance compared to the perpendicular orientation.

Simulations were also carried out to investigate the impact of the lattice on the transmission line. The results indicated increased transmission loss for the perpendicular orientation of around $1 \mathrm{~dB}$ whereas the parallel orientation had loss of around $0.5 \mathrm{~dB}$. In the perpendicular orientation the transmission line is parallel to the electrodes of the lattice. These results suggest that both the antenna and the transmission line couple to the electrodes of the lattice when they are parallel. 


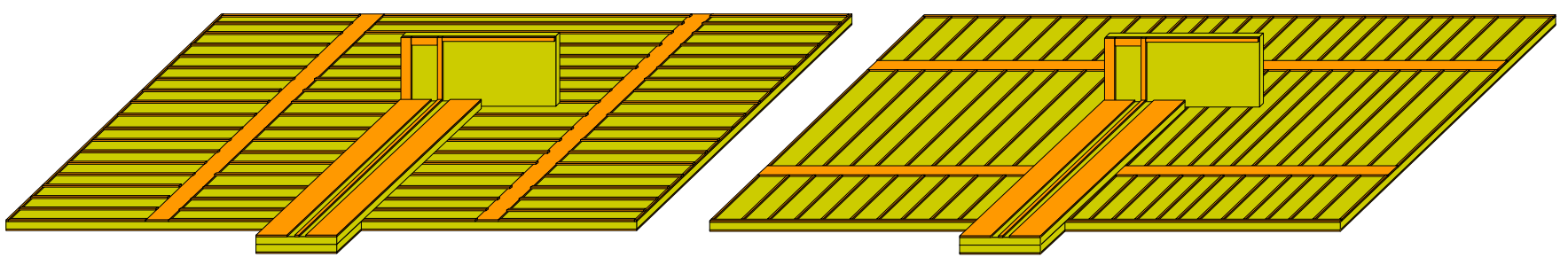

Figure 4. Parallel Antenna Orientation

Figure 5. Perpendicular Antenna Orientation

TABLE II. MEASURED AND SimUlated RESUlTS FOR DFFERENT ANTENNA ORIENTATIONS

\begin{tabular}{|l|c|c|}
\hline \multirow{2}{*}{ Antenna Orientation } & $\begin{array}{c}\mathbf{- 1 0 d B} \text { Bandwidth } \\
(\%)\end{array}$ & $\begin{array}{c}\text { Realised Gain } \\
(\mathbf{d B i})\end{array}$ \\
\cline { 2 - 3 } & Measured & Simulated \\
\hline Parallel to Lattice & 7.29 & 2.7 \\
\hline Perpendicular to Lattice & 5.40 & 1.9 \\
\hline FR-4 Covered Ground Plane & 4.93 & 3.1 \\
\hline
\end{tabular}

\section{LATTICE INTERACTION}

Ideally for a monopole to radiate properly it needs a conductive ground plane. In the case of the solar cell integration, the ground plane is covered by the latticed top layer of electrodes. These thin conductive bars which make up the lattice are likely to affect the antenna performance and radiation properties. Three models were used to investigate the effect of changing the lattice orientation on the antenna and transmission line combined. The first two models are shown in Fig. 4 and Fig. 5, the final model has an FR-4 covered ground plane with no lattice. These models take into account the effect of the lattice orientation on both the antenna and the transmission line.

\section{RESUlTS AND DisCUSSION}

The measured and simulated results are given in TABLE II. Fig. 6 shows the $S_{11}$ results for the perpendicular orientation both measured and simulated. Fig. 7 shows the $S_{11}$ results for the FR-4 covered ground plane.

The measured bandwidth of the antenna on the FR-4 covered ground plane was $4.93 \%$. This increased to $5.40 \%$ and $7.29 \%$. for the perpendicular and parallel orientations, respectively.
The antenna on the FR-4 covered ground had a simulated realised gain of $3.1 \mathrm{dBi}$, in the perpendicular orientation, a realised gain of $1.9 \mathrm{dBi}$ while in the parallel orientation the realised gain was $2.7 \mathrm{dBi}$. The reduction in simulated gain for both the parallel and perpendicular orientations compared to the FR-4 covered ground plane is an indicator of loss related to the presence of the lattice.

The frequency difference between the parallel and the perpendicular orientations indicate that the electrode lattice between the antenna and the ground plane has a small effect on the electrical length of the antenna. This is caused by the differing current flows on the lattice as it is excited by the antenna, in the parallel position current flow in the lattice is aligned with current flow in the antenna whereas in the perpendicular position current flow in the lattice is opposed to the current flow in the antenna. The result of this is an increase in the electrical length of the antenna in the perpendicular orientation and a downward shift in frequency.

The increase in the bandwidth of the measured antenna in both the parallel and perpendicular orientations compared to the FR-4 covered ground plane suggests that there are increased losses due to the interaction of the antenna with the solar lattice.

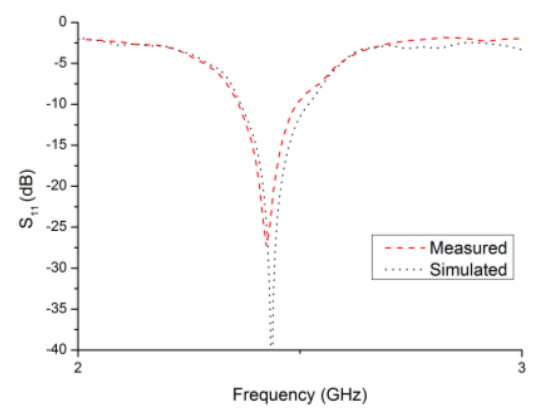

Figure 6. Perpendicular S11 Results

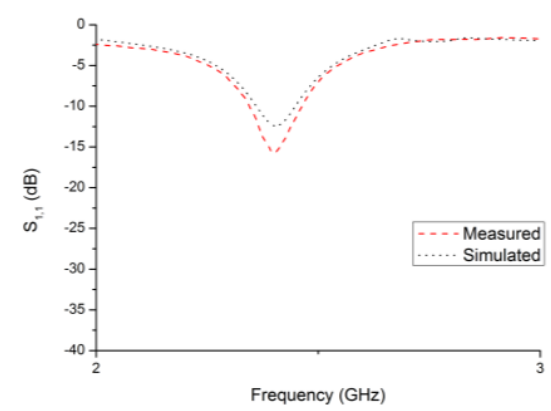

Figure 7. FR-4 Covered Ground Plane S11 Results 


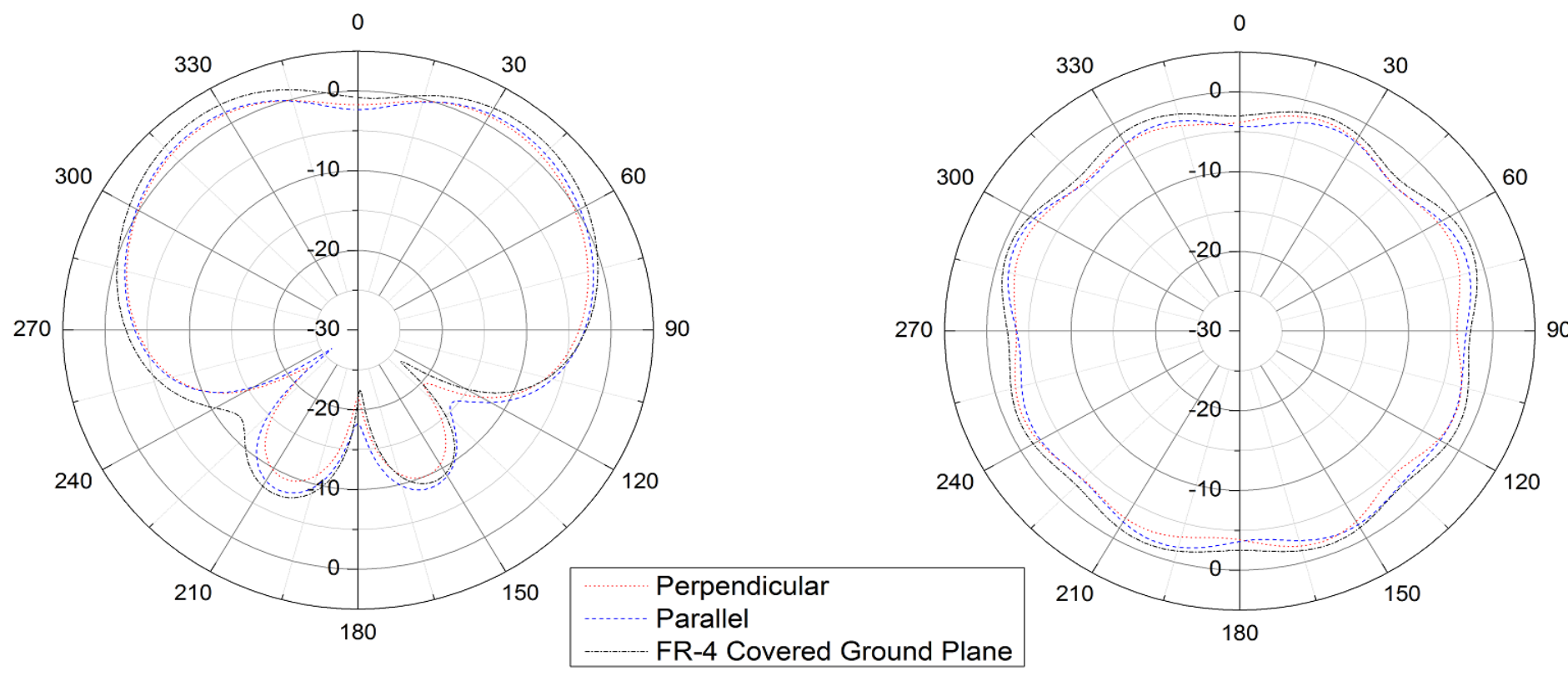

Figure 8. Simulated Radiation Patterns for E-Plane (Left) and H-Plane (Right)

\section{CONCLUSION}

Previous works have shown a reduction in antenna performance as a result of antenna orientation on a solar cell lattice using microstrip patch antennas. In this work an IFA antenna is used with an FR-4 solar cell substitute to assess its response to the orientation of the lattice of electrodes on the top contact of a solar cell. It has been shown that the lattice orientation affects both the transmission line and the antenna performance. Measured and simulated results show a small degradation in performance when the electrodes of the solar lattice are introduced, which would not preclude its use in wireless systems.

\section{REFERENCES}

[1] T. Wu, R. Li, and M. M. Tentzeris, "A Scalable Solar Antenna for Autonomous Integrated Wireless Sensor Nodes", IEEE Antennas and Wireless Propagation Letters, vol. 10, pp. 510-513, 2011.

[2] M. Tanaka, Y. Suzuki, K. Araki and R. Suzuki, "Microstrip antenna with solar cells for microsatellites", Electron. Lett., vol. 31, no. 1, pp. 56, 1995.

[3] S. Vaccaro, P. Torres, J. R. Mosig, A. Shah, J. F. Zurcher, A. K. Skrivervik, P. de Maagt and L. Gerlach, "Stainless steel slot antenna with integrated solar cells", Lectron. Lett., vol. 36, no. 25, pp. 20592060, 2000 .
[4] N. Henze, M. Weitz, P. Hofmann, C. Bendel, J. Kirchhof, H. Fruchting, "Investiation of Planar Antennas with Photovoltaic Solar Cells for Mobile Communications", IEEE International Symposium on Personal, Indoor and Mobile Radio Communications, vol. 1, pp. 622-624, 2004.

[5] S. V. Shynu, M. J. Roos Ons, G. Ruvio, M. J. Ammann, S. McCormack and B. Norton, "A Microstrip Printed Dipole Solar Antenna using Polycrystalline Silicon Solar Cells", IEEE AP-S International Symposium on Antenna and Propogation, pp. 1-4, 2008.

[6] M. J. Roo Ons, Shynu Nair, M. J. Ammann, S. McCormack and B. Norton, On Surface Currents in a Polycrystalline Solar Cell Acting as Ground Plane for Microstrip Patch Antennas, IEEE International Antennas \& Propagat. Symp. 2008, San Diego, CA.

[7] D. Liu and B. Gaucher, "The Inverted-F Antenna Height Effects on Bandwidth", IEEE Antenna and Propagation Society International Symposium, vol. 2A, pp. 367-370, 2005.

[8] C. M. Su and K. L. Wong, "Narrow flat-plate antenna for $2.4 \mathrm{GHz}$ WLAN operation", Electron. Lett., vol. 39, no. 4, pp. 344-345, 2003.

[9] D. Liu and B. Gaucher, "Performance Analysis of Inverted-F and Slot Antennas for WLAN Applications", IEEE Antenna and Propagation Society International Symposium, vol. 2, pp. 14-17, 2003.

[10] L. Pazin, N. Telzhensky and Y. Leviatan, "Wideband flat-plate invertedF laptop antenna for Wi-Fi/WiMAX operation", Microwaves, Antennas \& Propagation, IET, vol. 2, pp. 568-573, 2008.

[11] Y. S. Yang, M. C. Lee and S. J. Chung, "Two PIFA-Related Miniaturized Dual-Band Antennas", IEEE Transaction on Antennas and Propagation, vol. 55, pp. 805-811, 2007. 